\title{
Optimization of the ${ }^{32} \mathbf{P}$-postlabeling Assay for Detecting Benzo(a)pyrene-induced DNA Adduct Formation in Zacco platypus
}

\author{
Jin Wuk Lee and Sung Kyu Lee \\ Future Environmental Research Center
}

\begin{abstract}
Objectives: ${ }^{32} \mathrm{P}$-postlabeling assay is the most sensitive method of detecting DNA adduct formation. However, it is limited by a low sample throughput and use of radioisotopes (RI). In this study, we modified it to minimize these limitations and applied it to Z. platypus exposed to $\operatorname{Benzo}(a)$ pyrene $(\mathrm{B} a \mathrm{P})$ in order to investigate DNA adduct formation (effect biomarker for pollutants) in $Z$. platypus for assessing risk of waterborne $\mathrm{B} a \mathrm{P}$ exposure.

Methods: DNA hydrolysis was performed only with Micrococcal nuclease (MNase), RI reduction test was performed and the overlapping steps between thin layer chromatography (TLC) and radioisotope high-performance liquid chromatography (RI-HPLC) were omitted. The application of a modified method to Z. platypus exposed to $\mathrm{B} a \mathrm{P}$ was performed.

Results: The results revealed that the amount of RIs used can be reduced roughly 10-fold. Because the analysis time was shortened by 8.5 hours, the sample throughput per hour was increased compared with the previous method. The results of applying modified ${ }^{32} \mathrm{P}$-postlabeling assay to $Z$. platypus, DNA adduct formation in $Z$. platypus showed dose-dependency with the BaP concentration. Only BPDE-dGMP was detected as a DNA adduct.

Conclusion: These results demonstrate that the modified ${ }^{32} \mathrm{P}$-postlabeling assay is a suitable method for detecting DNA adduct formation in Z. platypus exposed to waterborne $\mathrm{B} a \mathrm{P}$ and will be useful in risk assessment of carcinogenic effect in aquatic environment due to $\mathrm{B} a \mathrm{P}$.
\end{abstract}

Keywords: ${ }^{32} \mathrm{P}-$ postlabeling assay, $\operatorname{Benzo}(a)$ pyrene, Zacco platypus

\section{Introduction}

Freshwater minnow (Zacco platypus) has been used as a model organism in toxicological studies at the population and individual levels. ${ }^{1-5)} \operatorname{Benzo}(a)$ pyrene $(\mathrm{B} a \mathrm{P})$ is a polycyclic aromatic hydrocarbon $(\mathrm{PAH})$ formed from the incomplete combustion of gasoline and organic matter. ${ }^{5,6}$ It is a ubiquitous environmental contaminant and classified by the International Agency for Research on Cancer (IARC) as a group 1 agent, labeling it as a human carcinogen. ${ }^{6,7)}$ Furthermore, $\mathrm{B} a \mathrm{P}$ has a high $\mathrm{K}_{\mathrm{ow}}$, resulting in its biomagnification up trophic levels, in fish. $^{5}$

$\mathrm{B} a \mathrm{P}$ is metabolized first by microsomal cytochrome p450s (CYPs) to several arene oxides, which undergo hydration to dihydrodiols via epoxide hydrase and epoxidation to diol epoxides. ${ }^{8}$ These intermediate metabolites can become conjugated to nucleotides. One intermediate metabolite of $\mathrm{B} a \mathrm{P}$ is $\mathrm{B} a \mathrm{P}-r$-7,t-8-dihydrodiol-t-9,10-epoxide (BPDE), which can bind to nucleic acids and become DNA adduct. ${ }^{8-10)}$ Generally, guanine is the primary DNA binding site of PAH intermediaries. DNA adducts are pre-

Corresponding author: Future Environmental Research Center, Gyeongnam Department of Environmental Toxicology and Chemistry, Korea Institute of Toxicology, Jinju, Gyeongsangnam-do,660-844, South Korea. Tel.:+82-55-750-3842, Fax:+82-55-750-3879, E-mail: yijinwuk79@gmail.com Received: 29 January 2014, Revised: 17 February 2014, Accepted: 25 February 2014 
mutagenic; they can cause DNA replication errors if not detected and repaired by cellular repair mechanisms and thus, DNA adduct formation has been used as effect biomarker which can be recognized as associated with an established or possible health impairment or disease..$^{9-11)}$

Carcinogenic DNA adducts can be detected and identified by several methods. One of the most sensitive is the ${ }^{32} \mathrm{P}$-postlabeling assay, developed in the early 1980s. ${ }^{10,12)}$ For some aromatic adducts, it has a detection limit as low as 1 adduct $/ 10^{10}$ nucleotides, using a sample as small as $10 \mu \mathrm{g} .{ }^{10)}$ However, the use of ${ }^{32} \mathrm{P}$-postlabeling assay is limited by a low sample throughput and using large amount of radioisotopes..$^{9,10,13,14)}$ In the present study, we developed the modified ${ }^{32} \mathrm{P}$-postlabeling assay method to increase sample throughput and to reduce radioisotope, comparing with the existing method. ${ }^{10,12)}$ DNA adducts formed in the liver of $Z$. platypus exposed to waterborne $\mathrm{B} a \mathrm{P}$ were detected using modified ${ }^{32} \mathrm{P}$-postlabeling assay. This study will facilitate the carcinogenic effect study for pollutants exposure such as $\mathrm{B} a \mathrm{P}$ in aquatic environment of Korea.

\section{Materials and Methods}

\section{Chemical reagents and instruments}

Proteinase $\mathrm{K}$ was purchased from Roche (Renzberg, Germany). Acetonitrile (ACN), ethyl acetate (EA), dichloromethane (DCM), and highperformance liquid chromatography (HPLC)-grade tetrahydrofuran (THF) was purchased from Burdick $\&$ Jackson (Muskegon, MI, USA). Benzo(a)pyrene$r$-7,t-8-dihydrodiol-t-9,10-epoxide ( \pm ) (anti) (BPDE) was purchased from NCI Chemical Carcinogen Repository, Midwest Research Institute (Kansas city, MO, USA). $3000 \mathrm{Ci} / \mathrm{mmol} \quad \gamma^{32} \mathrm{P}-\mathrm{ATP}$ ([ $\left.\left.{ }^{32} \mathrm{P}\right] \mathrm{ATP}\right)$ was purchased from Perkin-Elmer (Waltham, MA, USA). Other chemicals including $\mathrm{B} a \mathrm{P}$ were purchased from Sigma-Aldrich Co. (St. Louis, MO, USA). To analysis DNA adduct formation in the liver of $Z$. platypus which was exposed to waterborne $\mathrm{B} a \mathrm{P}$, UV-detector (Hewlett Packard, series 1100 G1315A DAD, CA, USA), RI-detector (PerkinElmer, Flow Scintillation Analyzer Radiomatic 610TR, Waltham, MA, USA), and mass detector (Hewlett-Packard, Series 1100 G1956B, CA, USA) were used.

\section{Fish maintain}

Zacco platypus were purchased from Damsunara Husbandry (Gyeong-gi Province, South Korea; 1year-old juvenile fish; length $=10.28 \pm 0.69 \mathrm{~cm}$, weight $=9.88 \pm 2.56 \mathrm{~g}$ ). The fish were bred in the laboratory for 6 months. They were fed $1 \%$ of their total weight of a commercial food every morning and evening (Powertechno $^{\circledR}$, Woosung Feed Co., Daejeon, South Korea). Dechlorinated tap water was used and fish were maintained at $22 \pm 1^{\circ} \mathrm{C}$ for breeding according to the OECD test guideline. ${ }^{15)}$

\section{BaP exposure and ${ }^{32} \mathbf{P}$-postlabeling assay}

We used liver as the test organ, because compared with other organs, fish liver has relatively high CYP1A specific activity, which is important in DNA adduct formation. Moreover, the liver has been proposed as the major site of CYP1A-catalyzed biotransformation in fish. ${ }^{16-18)} \mathrm{A}$ previous study revealed that low levels (1.2 and $0.4 \mu \mathrm{g} / \mathrm{L}$ ) of homogeneously dispersed $\mathrm{B} a \mathrm{P}$ in water did not cause DNA adduct formation, while high levels $(60 \mu \mathrm{g} / \mathrm{L})$ of homogeneously dispersed $\mathrm{B} a \mathrm{P}$ induced DNA adduct formation. ${ }^{19)}$ We selected 20 and $100 \mu \mathrm{g} / \mathrm{L}$ as the lower and upper concentrations, considering $60 \mu \mathrm{g} / \mathrm{L}$ as the median concentration.

Three fish were exposed to each $\mathrm{B} a \mathrm{P}$ concentrations: the control, $20 \mu \mathrm{g} / \mathrm{L}$, and $100 \mu \mathrm{g} / \mathrm{L}$. Liver tissue from the fish was subdivided for DNA isolation. The $\mathrm{B} a \mathrm{P}$ concentrations were maintained with a flowthrough exposure system. Dimethylformamide (Junsei, guaranteed grade, $0.01 \%(\mathrm{v} / \mathrm{v}))$ was used as the organic $\mathrm{B} a \mathrm{P}$ solvent. $\mathrm{B} a \mathrm{P}$ stock solution $(100 \mathrm{mg} /$ $100 \mathrm{ml}$ ) was supplied at $20 \mu \mathrm{l} / \mathrm{min}$ with syringe pumps which was purchased from Kloehn Co. Ltd. (Las Vegas, NV, USA) into a mixing chamber where carbon-filtered dechlorinated tap water was supplied at $200 \mathrm{ml} / \mathrm{min}$. The mixture was supplied to the treatment tanks. As a result, the tank water was changed once every $6 \mathrm{~h}$ during the 96 hour of $\mathrm{B} a \mathrm{P}$ exposure.

The photoperiod and water conditions were maintained based on OECD test guideline. ${ }^{15)} \mathrm{B} a \mathrm{P}$ exposure was performed during 96-hour (4-day). $\mathrm{B} a \mathrm{P}$ concentrations in control and $\mathrm{B} a \mathrm{P}$ exposure water were measured 0,2 , and $4 \mathrm{~d}$. The exposure water was condensed by 500 fold as follow method: $500 \mathrm{~mL}$ water of each group was eluted 
with one volume of dichloromethane (DCM), and DCM was evaporated with nitrate gase. And the $\mathrm{B} a \mathrm{P}$ was dissolved in $1 \mathrm{~mL}$ Acetonitriole (ACN). This ACN solution was analyzed with LC. The LC conditions were as follows: the column (phenyl-modified phase column, Zorbax Eclipse XDB-Phenyl, Agilent, Santa Clara, IL, USA) was eluted with the mobile phase (acetonitrile/Diluted Water (DW) $[8: 2, \mathrm{v} / \mathrm{v}]$ ) at $245 \mathrm{~nm}$ and the isocratic elution ran for $15 \mathrm{~min}$ with a flow rate of $1 \mathrm{ml} /$ min. We used a UV-detector (series 1100 G1315A DAD, Hewlett Packard, Santa Clara, IL, USA), a pump (series 1100 G1311A QuatPump, Hewlett Packard), and Chemstation for LC 3D software (Rev. A. 10.02 [1757], Aligent) for the LC. DNA was isolated using proteinase $\mathrm{K}$ followed by phenol/chloroform/isoamyl alcohol and precipitated with ethanol. The DNA was stored at $-80^{\circ} \mathrm{C}$. For the analyses, we placed $10 \mu \mathrm{g}$ of DNA in a 1.5$\mathrm{mL}$ tube and boiled the sample in a heating block for $30 \mathrm{~min}$, until it had completely evaporated. Then, we added $1 \mu \mathrm{L}$ of $50 \mathrm{mM} \mathrm{CaCl}, 1 \mu \mathrm{L}$ of $100 \mathrm{mM}$ bicine ( $\mathrm{pH} 9), 2 \mu \mathrm{L}$ of Micrococcal Nuclease (MNase) (0.2 units/iL), and $1 \mu \mathrm{L}$ DW, in a total volume of $5 \mu \mathrm{L}$. This was incubated at $37^{\circ} \mathrm{C}$ for $12 \mathrm{~h} .{ }^{9,20,21)}$ The DNA adducts were enriched and labeled according to previous studies. ${ }^{10,12)}$

A $10 \times 10$ Whatman no. 1 paper wick was stapled to the top edge of a $10 \times 10$ PEI-cellulose TLC sheet (Catalog No 1.05579.0001; Merck, Whitehouse Station, NJ, USA). Each sample was spotted onto the origin of the sheet, which was developed for $18 \mathrm{~h}$ with the wick hanging outside the tank in D1

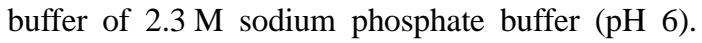
The adduct origin spot was cut from the TLC sheet and the TLC sheet origin powder was placed with $500 \mu \mathrm{L}$ pyridinium formate $(\mathrm{pH} 4.5)$ in a $2 \mathrm{~mL}$ brown glass tube. This was shaken gently for $16 \mathrm{~h}$ at room temperature and centrifuged $(5 \mathrm{~min}$, $3000 \mathrm{~g}$ ) to remove the TLC powder. The supernatant was decanted into a $2 \mathrm{~mL}$ glass tube. Quantification was performed with RI-HPLC under the conditions as follows. a Solvents A and B were $0.5 \mathrm{M}$ phosphate buffer (sodium, $\mathrm{pH} 3.5$ ) and acetonitrile (ACN)/tetrahydrofuran (THF) (5:5, v/ v), respectively. The column (phenyl-modified phase column) was eluted with liner gradient of sol. B (from 30 to $55 \%$ ) for $70 \mathrm{~min}$ in sol. A. The specific activity of the ATP was determined by $\left[{ }^{32} \mathrm{P}\right]$-labeling 300 fmol of 2'-deoxyadenosine3'-monophosphate (dAp). The dAp was labeled with $2.5 \mu \mathrm{Ci}$ of $\left[{ }^{32} \mathrm{P}\right] \mathrm{ATP}$ at $37^{\circ} \mathrm{C}$ for $30 \mathrm{~min}$ and the $10-\mu \mathrm{L}$ reaction mixture was diluted to $1 \mathrm{~mL}$ with DW. Next, $10 \mu \mathrm{L}$ of the diluted solution were spotted onto a PEI-cellulose TLC sheet, developed with $0.5 \mathrm{M}$ sodium phosphate buffer $(\mathrm{pH} 6)$, and quantified with RI-HPLC. The relative adduct level (RAL) was calculated by dividing the modified nucleotide dpm by the total nucleotide dpm.

\section{In vitro synthesis of BPDE-dGMP}

Zacco platypus genomic DNA diluted to $10 \mathrm{mg}$ / $10 \mathrm{~mL}$ of DW was boiled for $30 \mathrm{~min}$, and then hydrolyzed to deoxyribonucleosides using MNase $(0.08 \mathrm{unit} / \mu \mathrm{L})$ at $37^{\circ} \mathrm{C}$ for $12 \mathrm{~h}$. Other procedures followed the previous method. ${ }^{22)}$ To confirm BPDEdGMP synthesis, the BPDE-dGMP solution was analyzed with liquid chromatography electrospray mass spectroscopy (LC-API-ES-Mass). The following LC-APCI-Mass conditions were used. Solvents A and $\mathrm{B}$ were $0.5 \mathrm{M}$ sodium phosphate buffer $(\mathrm{pH} 3.5)$ and acetonitrile (ACN)/tetrahydrofuran (THF) $(5: 5, \mathrm{v} / \mathrm{v})$, respectively. The column (phenylmodified phase column) was eluted with liner gradient of sol. B (from 30 to 55\%) for $70 \mathrm{~min}$ in sol. A with a flow rate of $0.2 \mathrm{ml} / \mathrm{min}$, the mass detector was a Hewlett-Packard series 1100 G1956B, and the injection volume was $20 \mu \mathrm{l}$ (ion mode: positive). The instrumentation and software were the same as those used in the chemical exposure experiment. The synthesized BPDEdGMP was used as a standard material for in vivo DNA adducts.

The synthesized BPDE-dGMP was labeled with $\left[{ }^{32} \mathrm{P}\right]$ ATP. The ${ }^{32} \mathrm{P}$-labeled BPDE-dGMP was analyzed with RI-HPLC.

\section{Radioisotope reduction}

We reacted 300 fmol dAp with $\left[{ }^{32} \mathrm{P}\right]$ ATP in three conditions: $0.9 \mu \mathrm{Ci}+300$ fmol dAp; $2.5 \mu \mathrm{Ci}+300$ fmol dAp; and $25 \mu \mathrm{Ci}+300 \mathrm{fmol} \mathrm{dAp}$. There are $300 \mathrm{fmol}$ in $0.9 \mu \mathrm{Ci}$ of $\left[{ }^{32} \mathrm{P}\right] \mathrm{ATP}$, equimolar to $\mathrm{dAp}$; $2.5 \mu \mathrm{Ci}$ and $25 \mu \mathrm{Ci}$ have 840 and $8400 \mathrm{fmol}$, respectively. The reaction product, 2'-deoxyadenosine3',5'-diphosphate (pAp), was analyzed using TLC with $0.5 \mathrm{M}$ sodium phosphate buffer $(\mathrm{pH} 6)$ and the pAp dpm was measured with RI-HPLC.

\section{DNA hydrolysis test}

J Environ Health Sci 2014: 40(1): 000-000 


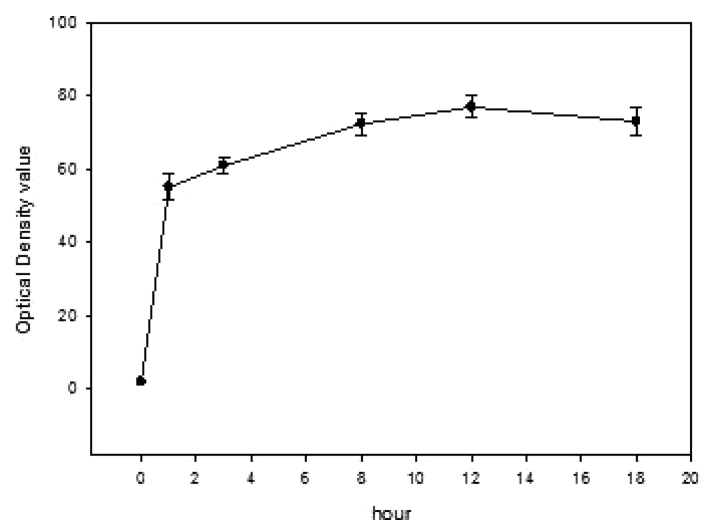

Fig. 1. Optical density at $260 \mathrm{~nm}$ for DNA digested with MNase. A one-way ANOVA followed by Tukey's test was used to detect significant difference among optical density (OD) values. Data were expressed as means \pm SD. from $8 \mathrm{~h}$ to $18 \mathrm{~h}$, significant increase of OD value was not observed.

We used MNase to digest the Z. platypus genomic DNA. To determine the optimal digestion period, the optical density (OD) of the DNA samples was measured at $260 \mathrm{~nm}$ throughout the digestion. The previous study recommended over night DNA digestion (over $16 \mathrm{~h}$ ). ${ }^{12)}$ According to the reference, the DNA had a high OD in proportion to the digestion level. ${ }^{21)}$ The Zacco platypus genomic DNA was digested by placing $10 \mu \mathrm{L}$ in 15 test tubes with MNase alone. The conditions were the same as for the ${ }^{32} \mathrm{P}$-postlabeling assay. At $1,3,12$, and $18 \mathrm{~h}$, the digested DNA in three test tubes was measured with a spectrophotometer (NanoDrop, Bioprince MiniSpectrophotometer SD-2000, China).

\section{Statistical analysis}

$t$-Tests were used to detect significant effects between $100 \mu \mathrm{g} / \mathrm{l} \mathrm{B} a \mathrm{P}$ exposure and the corresponding control groups. ${ }^{5)}$ A one-way ANOVA followed by Tukey's test was used to detect significant differences among species or $\mathrm{BaP}$ treated groups. Data were expressed as means \pm SD. All data were analyzed using Minitab $^{\circledR}$ for windows software (Minitab Inc., State College, PA, USA). Normality test for data was performed with Anderson-Darling test of Minitab ${ }^{\circledR}$. The $p$-value of below 0.05 was considered statistically significant.
A

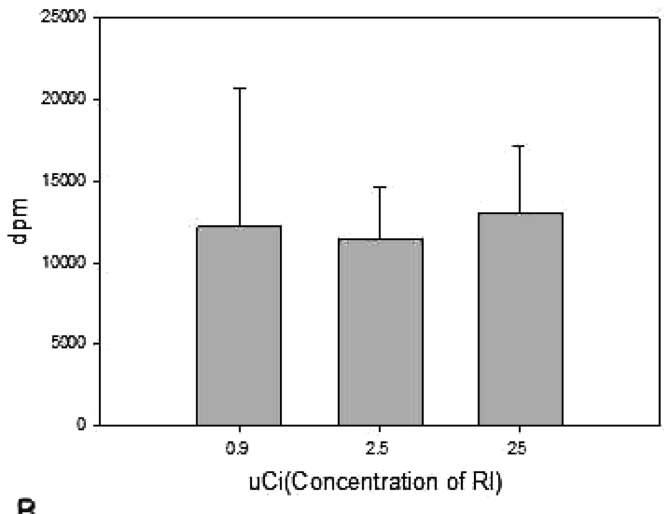

B

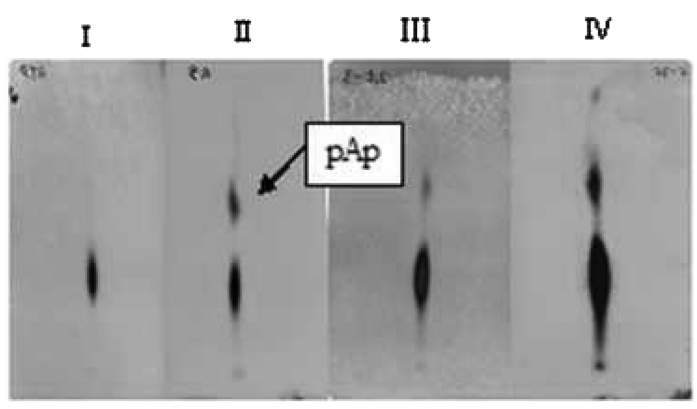

Fig. 2. Results of the study of the reduction test of the radioisotope material. (A) the dpm value of $\mathrm{pAp}$, resulting from reacting $300 \mathrm{fmol}$ of dAp with 300 $(0.9 \mu \mathrm{Ci}), 840(2.5 \mu \mathrm{Ci})$, and $8400(25 \mu \mathrm{Ci}) \mathrm{fmol}$ of RI. (B) X-ray film showing the results of the reaction of $300 \mathrm{fmol}$ dAp with $\left[{ }^{32} \mathrm{P}\right] \mathrm{ATP}$. (I) ${ }^{32} \mathrm{P}-\gamma$ ATP; (II) $0.9 \mu \mathrm{Ci}+300$ fmol dAp; (III) $2.5 \mu \mathrm{Ci}+$ $300 \mathrm{fmol}$; (IV) $25 \mu \mathrm{Ci}+300 \mathrm{fmol}$.

\section{Results}

\section{Modifying the ${ }^{32} \mathbf{P}$-postlabeling assay}

In the result of using MNase alone digestion, OD value reached the maximum level at $12 \mathrm{~h}$ after MNase treatment start $(0 \mathrm{~h})$ (Fig. 1). And then until $20 \mathrm{~h}$, the OD value had not been changed. The OD value at $12 \mathrm{~h}$ was similar with dNTP mixture value. Therefore, in this study DNA digestion was performed for 12 hours. This new digestion period was short than nature protocol by 4 hour.

In this study, reducing test of RI amount was performed by reacting $300 \mathrm{fmol}$ of dAp with various amounts of the RI $\left[{ }^{32} \mathrm{P}\right]$ ATP. There were three reaction conditions: $0.9 \mu \mathrm{Ci}\left(\left[{ }^{32} \mathrm{P}\right] \mathrm{ATP}, 300 \mathrm{fmol}\right)+300 \mathrm{fmol}$ 
Table 1. Comparison of the modified ${ }^{32} \mathrm{P}$-postlabeling assay method. In parentheses, the percentage represents reduction level relative to original protocol

\begin{tabular}{ccccccc}
\hline & $\begin{array}{c}\text { DNA } \\
\text { purification }\end{array}$ & $\begin{array}{c}\text { DNA } \\
\text { digestion }\end{array}$ & Enrichment & ${ }^{32} \mathrm{P}$-postlabeling & TLC analysis & $\begin{array}{c}\text { RI-HPLC } \\
\text { analysis }\end{array}$ \\
\hline $\begin{array}{c}\text { Original protocol } \\
\text { (Nature protocol) }\end{array}$ & $\begin{array}{c}\text { phenol } \\
\text { purification }\end{array}$ & $\begin{array}{c}\text { SPD \& MNase } \\
\text { used, }\end{array}$ & nuclease P1 & $25-50 \mu \mathrm{Ci}$ & $4^{\text {th }}$ development & $\begin{array}{c}70 \text { min, } \\
\text { gradient }\end{array}$ \\
\hline $\begin{array}{c}\text { Modified } \\
\text { protocol }\end{array}$ & unmodified & $\begin{array}{c}\text { MNase alone, } \\
\text { (Analysis time } \\
\text { reduced by 25\%) }\end{array}$ & unmodified & $\begin{array}{c}2.5 \mu \mathrm{Ci} \\
\text { (RI amount } \\
\text { reduced by 90\%)reduced by 20\%) }\end{array}$ & $\begin{array}{c}1^{\text {st }} \text { development } \\
\text { (Analysis time }\end{array}$ & unmodified \\
\hline
\end{tabular}

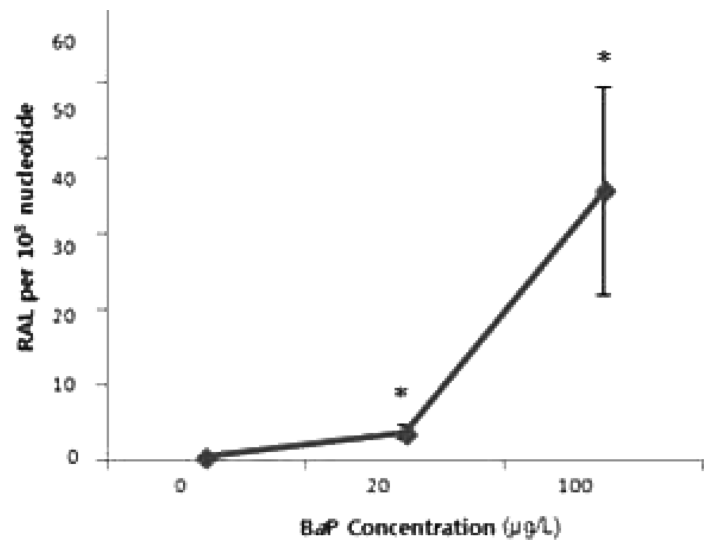

Fig. 3. The relative adduct level (RAL) value; the DNA adduct number per $1 \times 10^{8}$ total nucleotides and the $\mathrm{B} a \mathrm{P}$ exposure concentration. The data were represented as mean $\pm \mathrm{SD}$. Asterisk indicates values that are significantly higher than control values $(* p<0.05: t$-test, $\mathrm{n}=3)$.

dAp, $2.5 \mu \mathrm{Ci}\left(\left[{ }^{32} \mathrm{P}\right] \mathrm{ATP}, 0.84 \mathrm{pmol}\right)+300 \mathrm{fmol} \mathrm{dAp}$, and $25 \mu \mathrm{Ci}\left(\left[{ }^{32} \mathrm{P}\right]\right.$ ATP, $\left.8.4 \mathrm{pmol}\right)+300 \mathrm{fmol} \mathrm{dAp}$. The results revealed that using $2.5 \mathrm{iCi}$ and $25 \mu \mathrm{Ci}$ $\left(\left[{ }^{32} \mathrm{P}\right]\right.$ ATP, 8.4 pmol and 84 pmol) showed nonsignificant difference (one-way ANOVA, $p<0.05$ ). When Using $0.9 \mu \mathrm{Ci}\left(\left[{ }^{32} \mathrm{P}\right] \mathrm{ATP}, 300 \mathrm{fmol}\right)$, standard deviation is too high relative to the others. This result suggests that at least 10 fold reduction of RI did not significantly influence in DNA adduct detection (Fig 2). The modified results were shown in Table 1 .

2. Results applying the modified method and characterizing the DNA adduct synthesized in vitro

The only observed DNA adduct was BPDEdGMP, which was found at average concentrations of 52.3, 5.6, and $0.63 \mathrm{fmol}$ in the groups exposed to 100 and $20 \mu \mathrm{g} \mathrm{BaP} / \mathrm{L}$ and the control, respectively.
The amount of BPDE-dGMP observed revealed doesdependency with the $\mathrm{B} a \mathrm{P}$ exposure concentration (Fig. 3). The mass spectrum of LC-Mass analysis for synthesized BPDE-dGMP showed $\mathrm{m} / \mathrm{z} 650.3$ ion and $m / z, 303$ ion peak, revealing BPDE-dGMP and BPDE, respectively (Figs. 4 and 5). The same types of DNA adduct were observed both in vivo and in vitro production (Fig. 5).

\section{Discussion}

1. Modified method and in vivo and in vitro application

MNase digests DNA into mononucleotides and dinucleotides carrying 5'-hydroxyls and 3'phosphates, and Spleen phosphodiesterase (SPD) digests oligonucleotides with 5'-hydroxyls into mononucleotides, ${ }^{20,23)}$ and thus using two enzymes might be more efficient than using MNase alone. However, in case of Korea, the obtaining and use of SPD is difficult, because of the law of Livestock Epidemics Prevention, 32-1 that noted the region (34 nations including USA) in which the importing of hydrolyzed protein from ruminant livestock was banned. ${ }^{24)}$ And thus, we tried to digest DNA with only MNase. The results revealed that MNase alone digested DNA almost completely for 12-hour when comparing with the dNTP mixture which was fully separated into mononucleotides (Fig. 1). Analysis time was reduced by at about 4-hour relative to nature protocol recommending over 16-hour.

During development 1 (D1) and 2 (D2), DNA adducts remain at the origin but aqueous electrolytes (unreacted RIs, unreacted DNA monomer) migrate from the origin, and DNA adducts will migrate from origin in D3 and D4. ${ }^{12,25)}$ The previous study ${ }^{10)}$ mentioned that the origin after D1 could also be cut from the PEI-cellulose TLC sheet. This study 

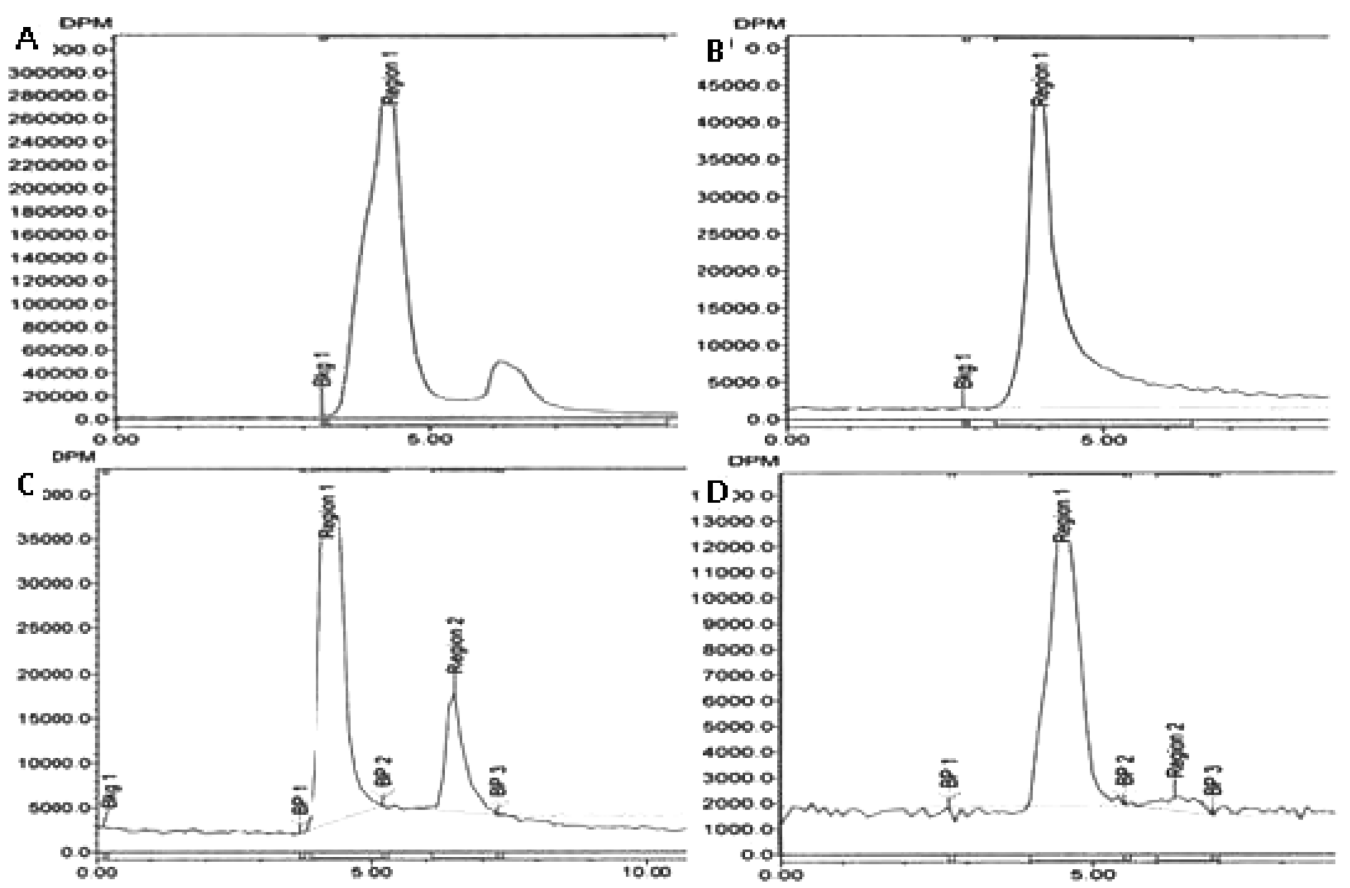

Fig. 4. The analysis results of DNA adduct formation. A: RI-HPLC chromatogram of the BPDE-dGMP standard. B: Chromatogram of ATP. C: chromatogram of BPDE-dGMP from livers of Z. platypus exposed to $100 \mu \mathrm{g} / \mathrm{L} \mathrm{B}(a) \mathrm{P}$. D. chromatogram of BPDE-dGMP from livers of $Z$. platypus exposed to $20 \mu \mathrm{g} / \mathrm{L} \mathrm{B}(a) \mathrm{P}$.

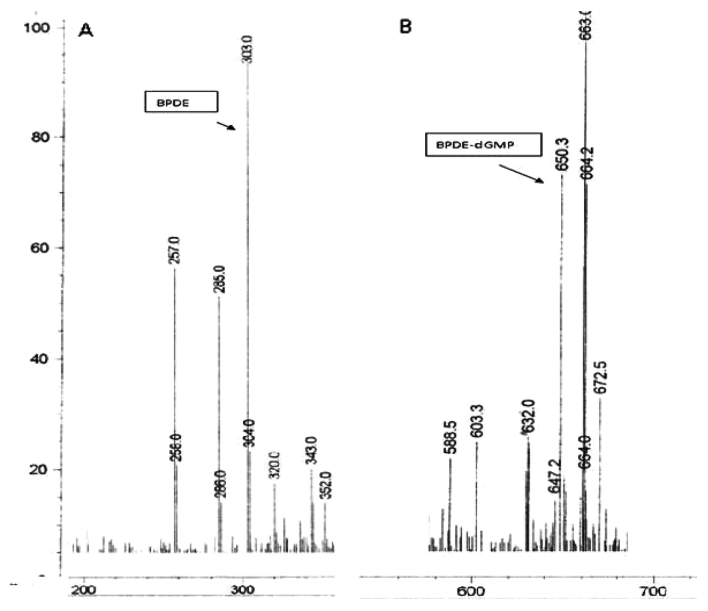

Fig. 5. The analysis results of DNA adduct formation. A: Ion spectrum of standard BPDE from LC/APCIMS analysis. B: Ion spectrum of standard BPDEdGMP (in vitro synthesized).

performed only D1, since D2, D3 and D4 were redundant, because firstly, D1 is sufficient for eliminating aqueous electrolytes, secondly, the purpose of RI-HPLC analysis was overlapped with D3 and D4 which separated DNA adducts.

The previous study mentioned that the combination of full TLC development steps and RI-HPLC will increase the resolution discriminating the difference among DNA adducts. ${ }^{10,12)}$ The purpose of this study was to investigate DNA adduct formation as effect biomarker for $Z$. platypus exposed to $\mathrm{B} a \mathrm{P}$ and increase the sample throughput. In this study, the information for the DNA adduct amount formed from $\mathrm{B} a \mathrm{P}$ exposure was more important than for DNA adducts discrimination. And thus, we eliminate D 2, 3, 4 TLC steps. Since after D1, the origin of TLC plate, in which DNA adducts remained was eluted with organic solvent, there was no loss of any kind of DNA adducts. Omitting TLC steps, analysis time was reduced relative to original method by 4.5 hours. ${ }^{10,11)}$

The previous study noted that phage T4 polynucleotide kinease will catalyze the exchange of a 5'-phosphage in a single-stranded oligonucleotide for a gamma-phosphate of ATP. ${ }^{26)}$ We examined the effect of reducing the quantity of RI used. ${ }^{32} \mathrm{P}$ - 
postlabeling assays typically use $25-50 \mu \mathrm{Ci}$ per sample. $^{10,12-14,27,28)}$ The previous study mentioned that the measured amount of DNA adducts in the field ranged from 0.03 to $17 \mathrm{fmol}^{28)}$ this amount was lower by $500-1000$ fold than $25-50 \mu \mathrm{Ci}$ which nature protocol recommended. Radioisotopes are the limiting reagent in bulk sampling. ${ }^{14)}$ Thus, we tried to reduce RI required in ${ }^{32} \mathrm{P}$-postlabeling assays.

We observed the same dpm values when various concentrations of $\left[{ }^{32} \mathrm{P}\right]$ ATP were reacted with one dAp concentration in ratios from 1:1 to $30: 1$. At the result, there was no significant difference of dpm value between $300 \mathrm{fmol} \mathrm{dAp}+2.5 \mu \mathrm{Ci}\left(\left[{ }^{32} \mathrm{P}\right] \mathrm{ATP}, 8.4\right.$ pmol) and 300 fmol dAp $+25 \mu \mathrm{Ci}\left(\left[{ }^{32} \mathrm{P}\right] \mathrm{ATP}, 84\right.$ pmol). The dpm value was not significantly different between the two conditions. From this, we determined that previous studies used excessive amounts of RI to detect unknown amount of DNA adducts. We determined at about $2.5-5 \mu \mathrm{Ci}$ was sufficient to detect unknown amount of DNA adducts in the field. The results revealed that the amount of RIs used can be reduced by about 10-fold.

Following $\mathrm{B} a \mathrm{P}$ exposure, the hepatic DNA adduct analysis revealed that $Z$. platypus formed pollutionrelated adducts, which can induce DNA damage. Only one type of DNA adduct, BPDE-dGMP, of which the chemical structure and characteristics are well known, was observed (Figs. 4 and 5). This result suggested that the DNA adduct expression pattern of $Z$. platypus was useful for study of waterborne $\mathrm{B} a \mathrm{P}$ exposure, because it provided information for exposure level and source.

\section{Species comparison and conclusions}

The DNA adduct pattern formed in Z. platypus is similar to that in carp, which belongs to the same family ${ }^{27)}$ but different in rainbow trout, which belongs to a different order, Salmoniformes. ${ }^{19}$ Carp produce more than $92 \%$ BPDE-dGMP. ${ }^{27)}$ But rainbow trout do not produce BPDE-dGMP. This suggested that there was the different capacity among species in forming $\mathrm{B} a \mathrm{P}$ reactive intermediates. In the study for rainbow trout, fish were exposed to constant low $\mathrm{B} a \mathrm{P}$ levels averaging $0.5 \mu \mathrm{g} / \mathrm{L}$ for 15 days, followed by a brief pulse of $60 \mu \mathrm{g} / \mathrm{L}$, declining to $2 \mu \mathrm{g} / \mathrm{L}$ for 15 days. ${ }^{19)}$ During the pulsed exposure, rainbow trout produced 1.3 adducts $/ 10^{7}$ nucleotides. ${ }^{19)}$ Interpolating this DNA adducts value between 20 and $100 \mu \mathrm{g} / \mathrm{L}$ in our data, 1.3 adducts $/ 10^{7}$ nucleotides fell in the middle. Thus,

http://www.kseh.org/ we hypothesize that while the mechanism which determines DNA adduct type differs between species, the mechanism that controls DNA adduct amount is similar across species. Finally, because only the pulsed exposure induced DNA adduct formation, the DNA adduct formation might be controlled by the $\mathrm{B} a \mathrm{P}$ exposure level, not duration. In the field, there were various pollutants and environmental conditions. And thus, further DNA adduct study for various pollutants and conditions is needed.

\section{Conclusions}

In this study, modified ${ }^{32} \mathrm{P}$-postlabeling assay reduced the RI amount used by about 10 fold that of existing method and overcame the limitation of low sample throughput, by reducing analysis time. 8.5 hours was reduced relative to original protocol and thus, total analysis time, 42 hours ( 2 days) was reduced into 34 hours. This result suggested that sample throughput per hour was increased. At the results of application of modified method to Z. platypus, only one DNA adduct, BPDE-dGMP, of which the chemical structure and characteristics are well-known, was detected both in vitro and in vivo. This result suggested that the DNA adduct expression pattern of Z. platypus was useful for study of waterborne $\mathrm{B} a \mathrm{P}$ exposure, because it provided information for exposure level and source if the standard materials was prepared. These results will facilitate the carcinogenic effect study to detect DNA adducts made by $Z$. platypus exposed to waterborne $\mathrm{B} a \mathrm{P}$ in the habitat of Z. platypus including South Korea.

\section{Acknowledgment}

This study was supported by the center for aquatic ecosystem restoration(CAER) of the Eco-STAR project from the ministry of environment, Korea.

\section{Conflict of interest}

The authors have no conflicts of interest with the material presented in this paper.

\section{References}

1. Berrebi P, Boissin E, Fang F, Cattaneo-Berrebi G. Intron polymorphism (EPIC-PCR) reveals phylo-

J Environ Health Sci 2014: 40(1): 000-000 
geographic structure of Zacco platypus in China: a possible target for aquaculture development. Heredity. 2005; 94(6): 589-598.

2. Kim IS, Kim HG. A study on the water pollution and its influence on the fish community in Jeonjucheon creek, Jeonrabug-do province, Korea. Kor $J$ Limnol. 1975; 8(3): 7-14.

3. Kwon YS, Li F, Chung N, Bae MJ, Hwang SJ, Byoen MS, et al. Response of fish communities to various environmental variables across multiple spatial scales. Int J Environ Res Publ Health. 2012; 9(10): 3629-3653.

4. Hur JW, Park SY, Kang SU, Kim J. Physical habitat assessment of Pale Chub (Zacco platypus) to stream orders in the Geum River Basin. Kor $J$ Environ boil. 2009; 27(4): 397-405.

5. Lee JW, Kim YH, Yoon SJ, Lee SK. Cytochrome P450 system expression and DNA adduct formation in liver of Zacco platypus following waterborne benzo(a)pyrene exposure: Implications for biomarker determination. Environ Toxicol. 2012; doi:10.1002/tox.21833.

6. Denton JE. Public Health Goal for Benzo(a)pyrene in Drinking Water. Public Health Goal (PHG) technical support document. California: Office of Environmental Health Hazard Assessment Press; 2010.

7. IARC. IARC monographs on the evaluation of carcinogenic risks to humans. Available : http:// monographs.iarc.fr/ENG/Classification [accessed 11 February 2014].

8. US Environmental Protection Agency. Drinking water criteria document for polycyclic aromatic hydrocarbons (PAHs), Final Report, EPA/600/X92/015. Washington DC: US Environmental Protection Agency Press; 1991.

9. Bend JR, James MO, Dansette PM. In vitro metabolism of xenobiotics in some marine animals. Ann NY Acad Sci. 1977; 298: 505-521.

10. Phillips DH, Arlt VM. The ${ }^{32}$ P-Postlabeling assay for DNA adducts. Nature Protocol. 2007; 2(11): 2772-2781.

11. Van der Oost R, Beyer J, Vermeulen NPE. Fish bioaccumulation and biomarkers in environmental risk assessment: a review. Environ Toxicol Pharmacol. 2003; 13(2): 57-149.

12. Phillips DH, Hewer A, Arlt VM. ${ }^{32} \mathrm{P}$-Postlabeling analysis of DNA adducts. Methods Mol Biol. 2004; 291: 3-12.

13. Armelle M, Saletta F, Aooilne A, Piro S, Confortini M, Matullo G, et al. ${ }^{32} \mathrm{P}-$ Postlabeling method improvements for aromatic compound-related molecular epidemiology studies. Mutagenesis. 2007; 22(6): 381-385.

14. Nagy E, Michael G, Möller CL. Accelerated 32P-
HPLC for bulky DNA adducts. Mutagenesis. 2008; 24(2): 183-189.

15. OECD. Guideline for testing of chemicals, guideline 203 Fish, acute toxicity test. Organization of Economic Cooperation Development. Paris: OECD Press; 1992.

16. Ray S, Bieger T, Scruton DA. ${ }^{32}$ P-Postlabeling analysis of aromatic DNA adducts in liver and brain of wild brook trout (Salvelinus fontinalis). Chemosphere. 1995; 30(4): 773-778.

17. Levine SL, Oris JT. CYP1A expression in liver and gill of rainbow trout following waterborne exposure: implications for biomarker determination. Aquat Toxicol. 1999; 46(3): 279-287.

18. Siroka Z, Drastichova J. Biochemical markers of aquatic environment contamination-cytochrome $\mathrm{P} 450$ in fish. A review. Acta Vet Brno. 2004; 73: 123-132.

19. Potter D, Clarius TM, Wright AS, Watson WP. Molecular dosimetry of DNA adducts in rainbow trout (Oncorhynchus mykiss) exposed to benzo(a)pyrene by different routes. Arch Toxicol. 1994; 69(1): 1-7.

20. Heins JN, Suriano JR, Taniuchi H, Anfinsen CB. Characterization of a nuclease produced by Staphylococcus aureus. J Biol Chem. 1967; 242(5): 1016-1020.

21. Sambook J, Russell DW. Molecular Cloning: A Laboratory Manual, 3rd ed. New York: Cold Spring Harbor Laboratory Press; 2001. p.65-69.

22. Canella K, Peltonen K, Dipple A. Identification of $(+)$ and $(-)$ anti benzo $(a)$ pyrene dihydrodiol epoxidenucleic acid adducts by the ${ }^{32} \mathrm{P}$-Postlabeling assay. Carcinogenesis. 1991; 12(6): 1109-1114.

23. Reddy MV, Gupta RC, Randerath K. ${ }^{32} \mathrm{P}$-Base analysis of DNA. Anal Biochem. 1981; 117(2): 271-279.

24. Korea Ministry of Goverment. The law of Livestock Epidemics Prevention, 32-1. Available: http:/ /www.law.go.kr/lsInfoP.do?lsiSeq=148785\#0000 [accessed 11 February 2014].

25. Watson WP. Review post-radiolabeling for detecting DNA damage. Mutagenesis. 1987; 2(5): 319-331.

26. Berkner KL, Folk WR. Polynucleotide kinase exchange reaction: quantitave assay for restriction endonuclease-generated 5'-phophoroyl termini in DNA. J Biol Chem. 1977; 252(10): 3176-3184.

27. Kurelec B, Krca S, Garg A, Gupta RC. The potential of carp to bioactivate benzo(a)pyrene to metabolites that bind to DNA. Cancer Lett. 1991; 57(3): 255-260.

28. Pfau W. DNA adducts in marine and freshwater fish as biomarkers of environmental contamination. Biomarkers. 1997; 2(3): 145-151. 